\title{
Dualism in the Labor Market: \\ A Perspective on the Lewis Model After Half a Century
}

\author{
Gary S. Fields \\ Cornell University \\ gsf2@cornell.edu
}

Revised Version: July, 2004

\begin{abstract}
This paper asks how the Lewis model might be viewed from the perspective of economic science half a century later. Many of the core propositions remain intact, some might be amplified, and a small number might be revised.
\end{abstract}




\title{
Dualism in the Labor Market: A Perspective on the Lewis Model After Half a Century
}

\author{
Gary S. Fields \\ Cornell University \\ Revised Version: July, 2004
}

\section{Introduction}

Much of Arthur Lewis's classic article "Economic Development with Unlimited Supplies of Labor" concerns labor market dualism. Writing as one who has worked with dualistic labor market models for many years (Fields 1972, 1975, 1979, 19891997 , forthcoming), I owe much of my intellectual heritage to Lewis and other early dual labor market adherents and modelers (Fei and Ranis, 1964; Harris and Todaro, 1970; Doeringer and Piore, 1971; Stiglitz, 1971, 1982).

This paper offers a fresh perspective after half a century on Lewis's seminal ideas regarding labor market dualism. The review brings in newer extensions and developments in economic thought in the intervening years. It also addresses some of the many criticisms that the Lewis model has received in, for example, early writings by Schultz (1964), Sen (1966, 1967b), and Rosenzweig (1988), as well as in the more recent textbook treatments by Basu (1997), Ray (1998), Perkins et al. (2001), and Todaro and Smith (2003). Lewis himself responded to some of the earlier critiques (Lewis, 1972) and Ranis (forthcoming) to some of the more recent ones.

The core of the paper is divided into five substantive sections: the essence of labor market dualism, models of the formal sector labor market, models of the informal sector labor market, intersectoral labor market linkages, and welfare economics. A brief conclusion follows. 


\section{The Essence of Labor Market Dualism}

At the core of the Lewis model is labor market dualism. One sector is that which is alternatively called "capitalist," "formal," "modern," "industrial," or "urban." The other is that which is alternatively called "subsistence," "informal," "traditional," "agricultural," or "rural." (At one point, I even called this latter one the "murky" sector.) In this paper, I shall use the formal/informal terminology.

Lewis explicitly wanted to build a dualistic model that fit some economies but by no means all (Lewis, 1954, pp. 140-141). The model was intended to be useful for economies such as those of Egypt, India, and Jamaica. It was explicitly not intended to be applicable to the United Kingdom or northwest Europe.

In my view, labor market dualism is a useful stylization of what later was called "labor market segmentation" or "labor market fragmentation." Why have just two sectors? Basu (1997, pp. 151-2) put it well:

The dual economy model of LDCs has had its demurrers. It has been pointed out that labor markets are often fragmented into more than two parts and also that dualism is not the distinguishing feature of underdevelopment because there are traits of it even in developed economies. These are not disturbing criticisms. It is unlikely that any of the initiators of the dual economy model would deny that the labor market may in reality be fragmented into more than two sectors. The assumption of duality is merely for analytical convenience. If fragmentation irrespective of the number of parts - in itself causes some problems and we wish to examine these, then the simplest assumption to make is that of dualism.

Along similar lines, Ranis (forthcoming) had this to say about a four-sector model: "Even though inter-sectoral relations become increasingly mind-blowing to trace, the basic asymmetries in labor market behavior remain critical for both analytical and policy purposes."

The literature has been quite ambiguous about the feature distinguishing these two sectors. The International Labour Organisation and the Economic Commission for Latin America and the Caribbean have defined the informal sector as enterprises employing 
five or fewer workers. In Brazil, the formal sector consists of workers who hold labor cards entitling them to various benefits and protections and the informal sector of those who do not. In other contexts, the formal sector is distinguished according to whether the firm is registered with the government and pays taxes. Yet others equate the informal economy with drugs, prostitution, and other illegal activities.

Lewis, in typical fashion, presented the difference between formal and informal employment in picturesque terms (Lewis, 1954, p. 147):

What we have is not one island of expanding capitalist employment, surrounded by a vast sea of subsistence workers, but rather a number of such tiny islands ... We find a few industries highly capitalized, such as mining or electric power, side by side with the most primitive techniques; a few high class shops, surrounded by masses of old style traders; a few highly capitalized plantations, surrounded by a sea of peasants. But we find the same contrasts also outside their economic life ... There is the same contrast even between people; between the few highly westernized, trousered, natives, educated in western universities, speaking western languages, and glorying Beethoven, Mill, Marx, or Einstein, and the great mass of their countrymen who live in quite other worlds.

In the Lewis model, the essence of labor market dualism is the fact that workers earn different wages depending on the sector of the economy in which they are able to find work. Lewis wrote (Lewis, 1954, p. 150): "Earnings in the subsistence sector set a floor to wages in the capitalist sector, but in practice wages have to be higher than this, and there is usually a gap of 30 per cent or more between capitalist wages and subsistence earnings." Lewis explained that although part of the gap is "illusory" because of the higher cost of living in the capitalist sector, there remained a real wage gap due to a) the "psychological cost of transferring from the easy going way of life of the subsistence sector to the more regimented and urbanized environment of the capitalist sector," b) the payoff to experience in the capitalist sector, and c) "workers in the capitalist sector acquiring tastes and a social prestige which have conventionally to be recognized by higher real wages." Later, in Lewis (1979), he assigned importance to the role played by labor unions and minimum wages. 
More recent writings on labor market dualism are grounded in human capital theory as developed by Schultz $(1961,1962)$, Becker $(1962,1964)$, and Mincer (1962, 1974). The subsequent labor dualism literature stressed that for dualism to exist, different wages must be paid in different sectors to comparable workers. Many researchers have found evidence of such dualism or segmentation; for one early compilation of evidence, see Fields (1980a). But Lewis was writing before human capital theory had been formulated, and so he should not be faulted much for failing to mention the comparability issue in his 1954 paper. Indeed, he later took up the matter at some length in Lewis (1979).

The idea that different wages are paid to comparable workers has been incorporated, largely without question, into job search theory, which also did not exist in Lewis's time. Since then, a whole class of models has arisen in which a wide variety of wages exist in the labor market, and workers are presumed to search among employers for the best possible opportunities. See, for instance, the textbook treatments of job search in Ehrenberg and Smith (2003) and Cahuc and Zylberberg (2004) See also the work on equilibrium wage distributions by Stiglitz (1985) and Burdett and Mortensen (1998).

Dualistic labor market models (or segmented labor market models more generally) have been criticized on other grounds. A recent Inter-American Development Bank report (IADB, 2003) puts it thus: "According to [the dualistic view of the labor market], the formal and informal economies operated in segmented labor markets and there is limited mobility between the two. Nothing could be further from the truth ... In a given six-month period, about 16 percent of workers in Mexico and 11 percent of workers in Argentina move either in or out of an informal job." Given the absence of panel data for developing countries in Lewis's time, he could not possibly have known what the rates of intersectoral mobility were. But even when we do know these rates, the fact remains that most workers remain in the sector in which they began. Economic mobility is a very important phenomenon, and indeed I am devoting a lot of my current 
research precisely to this issue, but I do so within the context of the dualistic labor market model.

We now take up in turn the formal sector labor market, the informal sector labor market, and the interactions between them.

\section{The Formal Sector Labor Market}

The major consequence of labor market dualism for Lewis is reflected in the title of his 1954 paper: "Economic Development with Unlimited Supplies of Labor." The novel feature of Lewis's framework was that the modern sector faces an unlimited supply of labor at wages only somewhat higher than subsistence levels. It is this that makes the Lewis model "classical," in contrast to a "neoclassical" model in which labor is scarce and has to be bid away from other uses. This feature was later elaborated by Ranis and Fei (1961), Fei and Ranis (1964), and Jorgenson (1967).

The unlimited supply of labor to the modern sector is sometimes called an "infinitely elastic supply curve of labor," but this designation is a misnomer. By definition, a supply curve tells the amount of something that is forthcoming as a function of the relevant price. Given the price of labor, the supply function delivers the unique quantity of labor available. Thus, in the Lewis model, when the formal sector wage is above the informal sector wage, the potential quantity of labor supplied to the formal sector is the entire labor force. However, because formal sector employers do not wish to employ all the workers who would like to work there at that wage, they (the employers) face an effectively unlimited supply of labor. Specifically, this means that no individual employer need raise the wage to attract additional labor, nor do employers as a whole within a substantial range. Indeed, there is a horizontal curve, but it is the wage as a function of employment, not the amount of labor supplied as a function of the wage.

The Lewis model is inherently dynamic, the mechanism being that over time, savings, investment, and capital accumulation produce economic growth in the formal 
sector of the economy. The source of this growth, for Lewis, was profits. He wrote (p. 157), "Practically all saving is done by people who receive profits or rents. Workers' savings are very small. The middle-classes save a little, but in practically every community the savings of the middle-classes out of their salaries are of little consequence for productive investment."

This line of argument can be questioned. Lewis, like others such as Kaldor (1956, 1957), assumed that the link from savings through investment through capital formation through economic growth took place only in the capitalist sector and only via profits. What if the capitalists use their profits for conspicuous consumption, investments in Swiss bank accounts, and purchases of Florida real estate? And on the other hand, what if the poor use their surplus to add fertilizer to the family farm, put a proper roof on the family house, and invest in the human capital of their children? For whom is the marginal propensity to form growth-producing capital higher? The answer is by no means evident, at least to me.

Turning now to employment in the modern sector, for Lewis, it was determined in a very neoclassical way: given the wage and the capital stock, employment is set according to the marginal product of labor. This feature of the model was not controversial at the time, nor is it controversial now. The process of savings, investment, capital formation, and economic growth just described shifts the marginal product of labor curve rightward, as shown explicitly in Lewis's Figure 3. Workers respond to the increased demand for labor in the formal sector by taking up employment there to the extent possible.

Over time, throughout a long range, the wage in the formal sector remains unchanged, because employers do not need to raise the wage to attract more labor. Then, however, a turning point is reached once the supply of labor to the formal sector is no longer unlimited. This change in behavior is discussed further in the section on intersectoral linkages below. 


\section{The Informal Sector Labor Market}

As modeled by Lewis, in the informal sector, the marginal product of labor is zero

or low - in any event, below the average product of labor. In Lewis's words (Lewis, 1954, p. 141):

An unlimited supply of labour may be said to exist in those countries where population is so large relatively to capital and natural resources, that there are large sectors of the economy where the marginal productivity of labour is negligible, zero, or even negative ... The phenomenon is not, however, by any means confined to the countryside. Another large sector to which it applies is the whole range of casual jobs - the workers on the docks, the young men who rush forward asking to carry your bag as you appear, the jobbing gardener, and the like. These occupations usually have a multiple of the number they need, each of them earning very small sums from occasional employment; frequently their number could be halved without reducing output in this sector." (Emphasis added)

Lewis then turned to wage determination in this sector. Income-sharing features

prominently is his work. In his words (Lewis, 1954, p. 142):

Most businesses in underdeveloped countries employ a large number of 'messengers', whose contribution is almost negligible; you see them sitting outside office doors, or hanging around in the courtyard. And even in the severest slump the agricultural or commercial employer is expected to keep his labour force somehow or other - it would be immoral to turn them out, for how would they eat, in countries where the only form of unemployment assistance is the charity of relatives? So it comes about that even in the sectors where people are working for wages, and above all the domestic sector, marginal productivity may be negligible or even zero.

One of the major criticisms of the Lewis model had to do with the combination of labor surplus and income-sharing. Lewis (1972) later wrote, "Whether marginal productivity is zero or negligible is not at the core of fundamental importance to our analysis ... This has led to an irrelevant and intemperate controversy." Ranis (forthcoming) now labels as "unfortunate" the choice of the "labor surplus" term and dismisses this critique as a "red herring." What matters, writes Ranis, is "that the 
marginal product is low, and sufficiently low to fall below the bargaining wage or income share."

In reviewing the original Lewis model and Fei and Ranis's amplification of it, a troublesome feature emerges: the nature of the subsistence wage in the informal sector. If the wage is literally a subsistence wage, below which people cannot subsist, then it has a natural floor. However, there is no sign that Lewis actually thought of the informal sector wage as the minimum needed for survival. Rather, it appears that he thought of the informal sector wage as a basic wage, lower than the real wage received by formal sector workers. The question, then, is whether this wage is a constant low wage or whether it varies (inversely) with the number of people in the sector.

From my reading of Lewis, there can be little doubt that he regarded production in the informal sector as subject to diminishing returns, a point that is explicit in Fei and Ranis's amplification of the Lewis model. Thus, when economic growth takes place and workers are drawn out of the informal sector into the formal sector, those who remain in the informal sector each receive a higher income than before; from my reading, this was first pointed out by Sen (1967a), and it was noted as well by Leeson (1979). The informal sector wage should not remain constant. Indeed, the rising wage in the informal sector is a reason for the unlimited supply of labor to the formal sector to run out eventually: because the supply price of labor to the formal sector will have risen due to improved wage opportunities in the informal sector.

The rising real wage in the informal sector has two implications. One is for the turning point, which we take up further in the next section. The other is for welfare analysis, which we take up in the section after that.

\section{Intersectoral Linkages in the Labor Market}

The Lewis model had a particular kind of intersectoral linkage: all workers not employed in the modern sector were assumed to take up employment in the agricultural 
sector. This is because, as noted above, the only form of assistance for the unemployed was the "charity of relatives" which was assumed (implicitly) to be available only to informal workers residing in the countryside.

Proceeding to a dynamic context, as employment in the modern sector expanded, the model held that additional workers would move from the informal to the formal sector. This process was dubbed "intersectoral shifts" in Kuznets (1955). I myself called it "modern sector enlargement" (Fields, 1979, 1980b).

An important feature of the Lewis model is that there was no open unemployment, only underemployment. The absence of unemployment was mirrored in the subsequent dualistic model of "crowding" developed in the labor market discrimination literature by Bergmann (1971).

In 1970, a major alternative was developed. Harris and Todaro (1970) formulated a model in which, to be hired for a formal sector job, it was necessary to be physically present in the urban areas where the formal sector jobs are located. In the Harris-Todaro model, more workers search for formal sector jobs than are hired. Those not hired end up unemployed ex post. Open unemployment, though a feature of the world, was not a feature of the Lewis model.

The Harris-Todaro model was first extended by Fields (1975) to allow for on-thejob search from rural agriculture, the existence of an urban informal sector, preferential hiring of the better-educated, and employment fixity. The model has subsequently been extended by many others.

Returning to the Lewis model, his characterization of intersectoral linkages generated two major predictions. The first is that as long as a labor surplus existed, economic growth would generate intersectoral shifts of employment but little or no increase in real wages in the formal sector. The second prediction is that once the unlimited supply of labor is exhausted and the turning point is reached, subsequent economic growth is marked by rising real wages economy-wide. 
The model proved to be remarkably prescient. Take the case of Taiwan, as illustrated in Figure 1. At the time Lewis was writing, the open unemployment rate was $6.3 \%$, higher than the generally agreed-upon level of full employment. In the next six years of Taiwan's economic growth, unemployment fell to $4.3 \%$ and real wages in manufacturing rose by only $2 \%$ (total, not per year), consistent with excess labor continuing to be supplied relative to the amount demanded. But then, in the next decade (the 1960s), unemployment fell to $1.5 \%$ - a rate indicating severe labor shortages - and real wages shot up by $81 \%$. Unemployment remained below $2 \%$ in the 1980 s and 1990 s, and real wages doubled again in each decade, not only in manufacturing but throughout the Taiwanese labor market.

The two phases predicted by Lewis appear clearly in the data for Taiwan: falling unemployment at essentially constant wages, then rapidly rising real wages at full or over-full employment. The dualistic model with intersectoral linkages tells a compelling story, and it did it before it happened.

The model remains relevant today. An article on offshoring published earlier this year (Meisler, 2004) said:

Amazing savings can be obtained by outsourcing information technology and business-process tasks to vibrant emerging economies like India. That giant country, say the experts, is currently the most employer-friendly because offshoring pioneers Ireland and Israel have maxed out their surplus labor pools, and salaries in those two countries have risen. [Emphasis added]

Not quite Lewis's rhetorical style but surely his idea! 
Figure 1.

Unemployment and Average Real Wages in Taiwan.
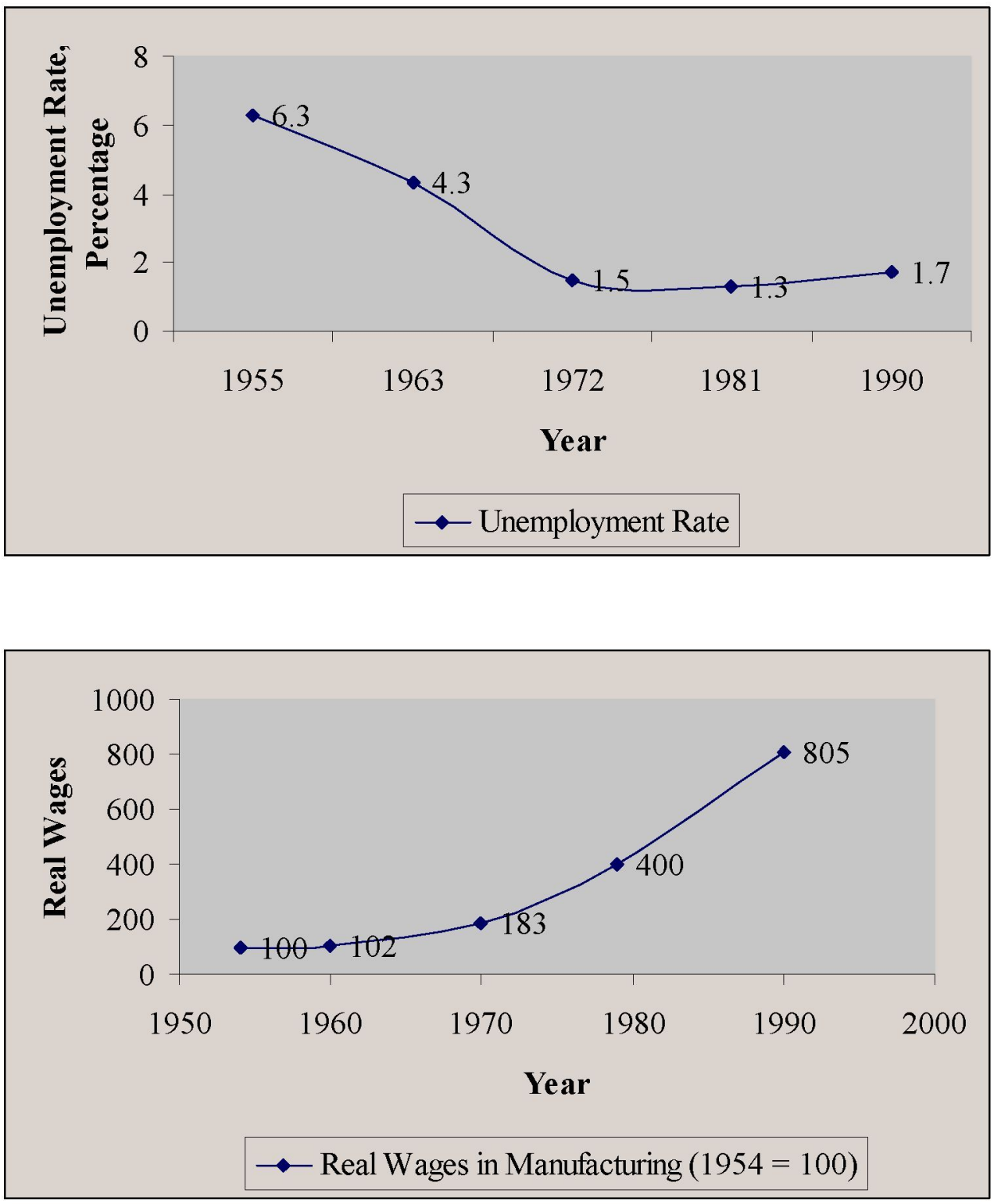

Sources: Fields (1984, 1994). 


\section{The Welfare Economics of Dualistic Development}

Lewis conducted his welfare analysis primarily in terms of total output and output growth. His concern was the concern of almost all of development economics of a half century ago: a near-exclusive interest in economic growth. Lewis's concern with economic growth to the virtual exclusion of all else in development was also manifested three decades later in his Nobel address (Lewis, 1984).

For Lewis, income distribution was of interest only to the extent that it affected the level and growth of aggregate output. Hence, in the Lewis model, the functional distribution of income was important, because the larger was the profit share of national income, the greater the resources available for savings, investment, capital formation, and subsequent economic growth (pp. 156-160). On the other hand, Lewis exhibited no interest in the size distribution of income, i.e., Lorenz curves, Gini coefficients, income shares of the richest $\mathrm{x} \%$ and poorest $\mathrm{y} \%$, and the like. In that sense, he was a man of his time. Coincidentally, in the same year as Lewis's famous paper (1954), Simon Kuznets delivered his equally-famous presidential address to the American Economic Association, in which he turned the profession's attention to the size distribution of income (published as Kuznets, 1955).

Lewis was, though, deeply concerned about poverty. Still, his writings manifested a certain inconsistency about whether economic growth with unlimited supplies of labor would or would not have a beneficial effect on poverty. As noted above, Lewis clearly had in mind that real wages and utility were higher in the formal sector than in the informal sector. Thus, each time a worker moved from the informal to the formal sector, that worker's economic well-being increased, which means that poverty in the economy should go down. At one point, Lewis appeared to be well aware of this (p. 158): "All that the workers get out of the expansion is that more of them are employed at a wage above the subsistence earnings." Note the phrasing, though: "All that the workers get ..." and not "What the workers get ..." But yet, in the summary of his article (Lewis, 1954, 
p. 190), he wrote: "Capital formation and technical progress result, not in raising wages, but in raising the share of profits in the national income." (Emphasis added.) Clearly, he was right in the first quotation and not in the second.

There was another omission as well. As noted above, it is clear that Lewis had in mind diminishing returns to labor in the informal sector, with the consequence that labor earnings rise within the informal sector as workers leave it. Viewed in today's terms, the rise in wages has an impact on the extent of poverty. Modern poverty indices such as the Sen index (Sen, 1976) and the $\mathrm{P}_{\alpha}$ index (Foster, Greer, and Thorbecke, 1984) and poverty dominance techniques (Atkinson, 1987; Ravallion, 1994) all view the extent of poverty as depending not only on how many poor people there are but also on how poor the poor are. But in Lewis's time, these indices and approaches had not been invented yet. So although we today think of poverty falling among those who remain in informal employment, Lewis would have been thinking of poverty in terms of the poverty headcount instead.

Putting the two preceding arguments together, we have seen that modern sector enlargement has two beneficial effects on poverty. One is that poverty falls among those workers who are able to move from the informal sector to the formal sector. The other is that poverty falls among the workers who remain informal. Contrary to Lewis's summary statement, wages do rise in his model via these two mechanisms, and poverty is correspondingly reduced as Lewis-type growth takes place.

\section{Conclusion}

The time has come to summarize how Lewis's formulation of dualism in the labor market might be viewed half a century later. Overall, his model has stood up remarkably well. Specifically: 
1. Lewis's version of labor market dualism was a pathbreaking analytical starting point for the economies about which he was writing. It remains a useful characterization of some economies today.

2. Sadly, some countries' modern sectors face an essentially unlimited supply of labor remains today. Lewis's rendition of the modern sector enlargement growth process remains insightful, though there may be more scope for capital formation arising from workers' wages than Lewis suspected.

3. Lewis's characterization of the informal sector entailed labor being paid the average product of labor or some function of the average product, with substantial income sharing taking place. This too remains a meaningful feature of poor economies today.

4. The intersectoral links posited by Lewis involved a simple rule: anyone not employed in the formal sector is assumed to be employed in the informal sector. Labor migration took place in Lewis's context when and only when new formal sector employment opportunities opened up. Newer models allow for open unemployment and for on-the-job search. Nonetheless, empirical evidence supports Lewis's two major turning point predictions.

5. Lewis's welfare economics was primarily in terms of growth, with only limited attention to inequality and poverty. Today's analyses would place much more emphasis on the poverty-reduction effects of Lewis-type economic development than Lewis did. 


\section{References}

Atkinson, Anthony B. (1987). “On the Measurement of Poverty,” Econometrica 55: 749764 .

Basu, Kaushik (1997). Analytical Development Economics. (Cambridge, MA: MIT Press).

Becker, Gary S. (1962). "Investment in Human Capital," Journal of Political Economy. LXX Supplement: 9-49.

Becker, Gary S. (1964). Human Capital. (New York: Columbia University Press for the National Bureau of Economic Research).

Bergmann, Barbara (1971). "The Effect on White Incomes of Discrimination in Employment," Journal of Political Economy 79: 294-313.

Burdett, Kenneth and Dale Mortensen (1998). "Wage Differentials, Employer Size, and Unemployment," International Economic Review 39: 257-273.

Cahuc, Pierre and André Zylberberg (2004). Labor Economics. (Cambridge, MA: MIT Press).

Doeringer, Peter B. and Michael J. Piore (1971). Internal Labor Markets and Manpower Analysis. (Lexington, MA: Heath).

Ehrenberg, Ronald G. and Robert S. Smith (2003). Modern Labor Economics. (Boston: Addison Wesley).

Fei, John C.H. and Gustav Ranis (1964). Development of the Labor Surplus Economy. (Homewood, IL: Irwin).

Fields, Gary S. (1975). "Rural-Urban Migration, Urban Unemployment and Underemployment, and Job Search Activity in LDC's," Journal of Development Economics 2: 165-188.

Fields, Gary S. (1979). "A Welfare Economic Approach to Growth and Distribution in the Dual Economy, Quarterly Journal of Economics 372: 325-354.

Fields, Gary S. (1980a). "Education and Income Distribution in Developing Countries: A Review of the Literature," in Timothy King, ed., Education and Income. (Washington: World Bank).

Fields, Gary S. (1980b). Poverty, Inequality, and Development. (New York: Cambridge University Press). 
Fields, Gary S. (1984). "Employment, Income Distribution and Economic Growth in Seven Small Open Economies," The Economic Journal, 94: 74-83.

Fields, Gary S. (1989). "On-the-Job Search in a Labor Market Model: Ex-Ante Choices and Ex-Post Outcomes," Journal of Development Economics, 30: 159-178.

Fields, Gary S. (1994). "Changing Labor Market Conditions and Economic Development in Hong Kong, the Republic of Korea, Singapore, and Taiwan, China," The World Bank Economic Review 8: 395-414.

Fields, Gary S. (1997). "Wage Floors and Unemployment : A Two Sector Analysis," Labour Economics 4: 85-92.

Fields, Gary S. (forthcoming). "A Welfare Economic Analysis of Labor Market Policies in the Harris-Todaro Model," Journal of Development Economics.

Foster, James E., Joel Greer, and Erik Thorbecke, "A Class of Decomposable Poverty Measures," Econometrica 52: 761-766.

Harris, John and Michael Todaro (1970). "Migration, Unemployment, and Development: A Two Sector Analysis," American Economic Review, 40: 126-142.

Inter-American Development Bank (2003). Good Jobs Wanted. (Washington: InterAmerican Development Bank).

Jorgenson, Dale W. (1967). "Surplus Agricultural Labour and the Development of a Dual Economy," Oxford Economic Papers 19: 288-312.

Kaldor, Nicholas (1956). "Alternative Theories of Distribution," Review of Economic Studies 23: 83-100.

Kaldor, Nicholas (1957). “A Model of Economic Growth," The Economic Journal 67: 591-624.

Kuznets, Simon (1955). "Economic Growth and Income Inequality," American Economic Review 45: 1-28.

Leeson, Philip F. (1979). "The Lewis Model and Development Theory," The Manchester School 47: 196-210.

Lewis, W. Arthur (1954). "Economic Development with Unlimited Supplies of Labour," Manchester School, 22: 139-191. 
Lewis, W. Arthur (1972). "Reflections on Unlimited Labor," in Luis DiMarco, ed., International Economics and Development: Essays in Honor of Raul Prebisch. (New York: Academic Press), 75-96.

Lewis, W. Arthur (1979). "The Dual Economy Revisited," The Manchester School 47: 211-229.

Lewis, W. Arthur (1984). "The State of Development Theory." American Economic Review 74: 1-10.

Meisler, Andy (2004). "Think Globally, Act Rationally," Workforce Management, January: 40-45.

Mincer, Jacob (1962). "On-the-Job Training: Costs, Returns, and Some Implications," Journal of Political Economy. LXX Supplement: 50-79.

Mincer, Jacob (1974). Schooling, Experience, and Earnings. (New York: Columbia University Press for the National Bureau of Economic Research).

Perkins, Dwight, Stephen Radelet, Donald Snodgrass, Malcolm Gillis, and Michael Roemer (2001). Economics of Development. (New York: Norton).

Ranis, Gustav (forthcoming). "Is Dualism Worth Revisiting?" in Alain de Janvry and Ravi Kanbur, eds., Poverty, Inequality, and Development: Essays in Honor of Erik Thorbecke.

Ranis, Gustav and John C. H. Fei (1961). "A Theory of Economic Development," American Economic Review, 51: 533-565.

Ravallion, Martin (1994). Poverty Comparisons. (Chur, Switzerland: Harwood).

Ray, Debraj (1998). Development Economics. (Princeton: Princeton University Press).

Rosenzweig, Mark (1988). "Labor Markets in Low Income Countries," in Hollis Chenery and T.N. Srinivasan, eds., Handbook of Development Economics, Volume 1.

(Amsterdam: North Holland).

Schultz, T.W. (1961). "Investment in Human Capital," American Economic Review. LI: $1-17$

Schultz, T.W. (1962). "Reflections on Investment in Man," Journal of Political Economy. LXX Supplement: 1-8.

Schultz, T.W. (1964). Transforming Traditional Agriculture. (New Haven: Yale University Press). 
Sen, Amartya K. (1966). "Peasants and Dualism With and Without Surplus Labor," Journal of Political Economy 74: 425-450.

Sen, Amartya K. (1967a). "Review of J.C.H. Fei and G. Ranis, Development of the Labor Surplus Economy: Theory and Policy," The Economic Journal 77: 346-349.

Sen, Amartya K. (1967b). "Surplus Labor in India: A Critique of Schultz' Statistical Test," Economic Journal 77: 154-161.

Sen, Amartya K. (1976). "Poverty: An Ordinal Approach to Measurement," Econometrica. 44: 219-231.

Stiglitz, Joseph E. (1971). "Alternative Theories of Wage Determination and Unemployment in LDC's," University of Nairobi, processed.

Stiglitz, Joseph E. (1982). "The Structure of Labor Markiets and Shadow Prices in LDCs," in Richard H. Sabot, ed., Migration and the Labor Market in Developing Countries. (Boulder, CO: Westview).

Stiglitz, Joseph E. (1985). "Equilibrium Wage Distributions," The Economic Journal. 95: 595-618

Todaro, Michael P. and Stephen C. Smith (2003). Economic Development. (Boston: Addison Wesley). 